\title{
Preparation and Characterization of Bimetallic Catalyst (NiO - CoO) for Desulfurization of Gas Oil
}

\author{
Jalil R. Ugal \\ Asmaa H. Hussein \\ Department of Chemistry, College of Science for Women, University of Baghdad \\ E-mail: R.Ugal@yahoo.com
}

Received 22/9/2015

Accepted 20/12/2015

(1) 9

EY NC ND This work is licensed under a Creative Commons Attribution-NonCommercialNoDerivatives 4.0 International Licens

\begin{abstract}
:
In this study $\mathrm{NiO}$ - $\mathrm{CoO}$ bimetallic catalysts are prepared with two $\mathrm{Ni} / \mathrm{Co}$ ratios (70:30 and 80: 20) using the precipitation method of nitrate salts. The effects of $\mathrm{Ni}$ /Co ratio and preparation methods on the catalyst are analyzed by using different characterization techniques, i.e. atomic absorption (AA), XRD, surface area and pore volume measurements according to the BET method .

The results indicate that the best catalyst is the one containing the percentage of $\mathrm{Ni}: \mathrm{Co}(70: 30)$. Experiments indicate that the optimal conditions to prepare catalyst are stirring for three hours at a temperature of $60^{\circ} \mathrm{C}$ of the preparation ، $\mathrm{pH}=(8-9)$, calcination temperature at $400^{\circ} \mathrm{C}$ for two hours using the impregnation method.

The catalyst activity is studied through the application in the process of oxidative desulfurization of gas oil fuel. The optimal conditions for deep oxidative desulfurization processes are : catalysts $3 \%, 2 \mathrm{gm} . \mathrm{Na}_{2} \mathrm{CO}_{3}$, refluxe time 3 hours at $40^{\circ} \mathrm{C}$, using a mechanical stirrer at moderate speed (700 $\mathrm{rpm}$ ), the volume ratio of gas oil : $\mathrm{H}_{2} \mathrm{O}_{2}$ : acetic acid is 10: 1: 0.5 and extracted with 1:1 ratio of acetonitrile to the gas oil for three times .

The results indicate that the catalysts are efficient to remove sulfur from gas oil depending on temperature, time, concentration of hydrogen peroxide $\mathrm{H}_{2} \mathrm{O}_{2} 30 \%$ and solvent used for extraction.

The efficiency of the best catalyst gives a maximum sulfur removal reaching $68.97 \%$.
\end{abstract}

Key words: Bimetallic Catalyst, N i- Co, Desulfurization, Gas Oil.

\section{Introduction:}

A catalyzed reaction is faster than an unanalyzed version of the same reaction because the catalyst provides a different reaction pathway with lower activation energy [1]. Generally, catalysts can be classified into heterogeneous or homogeneous, depending on whether a catalyst exists in the same phase as the substrate or not . Biocatalysts (enzymes) are often seen as a separate group $[1,2]$. 
Catalysts are widely used in nature, in industry, and in the laboratory. It is estimated that they contribute to onesixth of the value of all manufactured goods in industrialized countries [1].

The suitability of a catalyst for an industrial process depends mainly on the following three properties [3]:

1- Activity.

2- Selectivity.

3- Stability.

The major advantages/disadvantages of heterogeneous vs. homogeneous catalysts are summarized in Table (1) [4].

Table (1): Comparison of Main Advantages / Disadvantage of Heterogeneous vs. Homogeneous Catalysts

\begin{tabular}{|c|c|c|}
\hline Property & Homogeneous & Heterogeneous \\
\hline Catalysts activity & $\begin{array}{c}\text { difficult and } \\
\text { expensive }\end{array}$ & easy and cheap \\
\hline Stability & poor & good \\
\hline Selectivity & $\begin{array}{c}\text { excellent /good- } \\
\text { single } \\
\text { active site }\end{array}$ & $\begin{array}{c}\text { good/poor- } \\
\text { multiple } \\
\text { active site }\end{array}$ \\
\hline
\end{tabular}

The term green catalytic processes have been used frequently in recent years, implying that chemical processes may be made environmentally begin by taking advantage of the possible high yields and selectivities for the target products, with little or no unwanted side products and also often high energy efficiency and implying the catalysts to play a steadily increasing role in achieving a cleaner environment. An example is the reduction of hydrocarbons from automobile exhaust gases [5].

Sulfur enters our atmosphere as gaseous sulfur dioxide through the burning of fossil fuels such as diesel. Sulfur is also converted to sulfur trioxide $\left(\mathrm{SO}_{3}\right)$ and hydrogen sulfide $\left(\mathrm{H}_{2} \mathrm{~S}\right)$. Oxidative desulfurization of fuels is a matter of major interest not only because of increasing environmental concern. Sulfur dioxide $\mathrm{SO}_{2}$ affects the environment, man-made structures, our health, and even the industries that generate the toxic gases. It combines with water vapor in the air to form sulfurous and sulfuric acid. These acids fall back to earth in water vapor and slowly devour away stone. The gas easily corrodes steel and iron structures as well. More importantly, sulfur emissions affect our health and environment and have been correlated with higher incidences of asthma, lung disease, heart disease, and bronchitis. Finally, sulfur poisons the catalysts used in oil and gas refineries and in the catalytic diesel particulate filters of vehicles that are designed to eliminate the very problem of pollution [6].

The oxidative desulfurization (ODS) technology has been widely recognized as one of the most effective methods for the sulfur removal of fuel oils; due to the very mild operation conditions it requires [7].

\section{Materials and Methods:}

All reagents and solvents used are available commercially, which are nickel nitrate $\mathrm{Ni}\left(\mathrm{NO}_{3}\right)_{2} \cdot 6 \mathrm{H}_{2} \mathrm{O}$, cobalt nitrate $\mathrm{Co}\left(\mathrm{NO}_{3}\right)_{2} \cdot 6 \mathrm{H}_{2} \mathrm{O}$, sodium bicarbonate, barium chloride, hydrogen peroxide, acetic acid, sodium carbonate and acetonitrile .

Some physical and chemical properties for the gas oil form Al-Dura Refinery are listed on Table 2.

Table (2): Some Physical and Chemical Properties for the Gas Oil Sample Used

\begin{tabular}{|c|c|c|}
\hline Properties & Value & Standard \\
\hline Sp.gr at $15.6\left({ }^{\circ} \mathrm{C}\right)$ & 0.85 & 0.85 \\
\hline Flash Point $\left({ }^{0} \mathrm{C}\right)$ & 54 & 54 \\
\hline API - Gravity & 31.9 & 31.9 \\
\hline $\begin{array}{c}\text { Total sulfur } \\
\text { content wt.\% }\end{array}$ & 1.477 & 1.0 \\
\hline
\end{tabular}

API = American Petroleum Institute. 


\section{Catalyst Preparation:}

Catalyst $(\mathrm{NiO}-\mathrm{CoO})$ is prepared according to precipitation methods. The six basic preparation steps are used in the synthesis of the catalysts in our laboratory. The preparation methods are described as follows [8]:

1) Solution Preparation : The solution containing various metal salts $(\mathrm{Ni}-$ Co) is prepared through dissolving metal precursors using distilled water according to the desired ratio as ( 70:30 and 80: 20 ).

2) Precipitation: The precipitation of metals is made through adjusting the $\mathrm{pH}$ value of the solution to be $8-9$ by adding precipitating reagent. In this research, mild basic compounds are sodium bicarbonate $\mathrm{NaHCO}_{3}(1.0 \mathrm{M})$ ,the contents are continuously stirred during precipitation and agitation at 60 ${ }^{\mathrm{C}} \mathrm{C}$ for 3 hours.

3) Filtration and Washing: Filtration is used to remove most of water and unwanted ions through a Buchner funnel in vacuum. The cake remaining after filtration is washed using distilled water at room temperature until the $\mathrm{pH}$ value of washing flow is close to 7 , with being sure that the filtrate is free from sodium ions as well as drops of barium chloride $(0.1 \mathrm{M})$ are added to the filtrate as filtrate turbidity means the presence of sodium ions and continue panning with water until it is free.

4) Drying: After removing most of unwanted ions by washing, the precipitated cake contains a significant portion of water. The precipitate is then dried in an oven at $120{ }^{\circ} \mathrm{C}$ for 24 hours to remove the water.

5) Calcination: The catalyst calcination is one of the most important pretreatment procedures. Calcination temperature is at $400{ }^{\circ} \mathrm{C}$ for 2 hours in a muffle furnace. Thermally unstable compounds in the catalyst are decomposed to oxides. High temperature process can generate strong interaction between metals and oxide support, resulting in the formation of stable catalysts.

6)Forming Operation: After calcination, the catalyst is grinded and formed as pellets .

\section{Catalyst Characterization:}

The prepared catalysts are characterized by using different techniques. The metal contents of the catalysts are determined by the atomic absorption (AA) technique. The specific surface area and pore volume are measured according to the Brunauer Emmett - Teller (BET) method. The crystal structure and determination of crystallographic parameters of the metal oxides forming the catalysts are performed by XRD analysis .

\section{Experimental Procedure and Analysis:}

The catalyst activity is studied through its application in the process of oxidative desulfurization of gas oil which involves the following steps :

\section{Oxidative Desulfurization Procedure:}

1- A sample $100 \mathrm{ml}$ of gas oil from AlDura Refinery is put in a round bottom flask with three-necks in water bath . The sample content of sulfur is of $1.407 \%$.

2- The wanted weight (3) $g$ of the catalyst is previously added to the flask .

3- $10 \mathrm{ml}$ of $30 \% \quad \mathrm{H}_{2} \mathrm{O}_{2}$ as an oxidizing agent is added to the flask followed by $5 \mathrm{ml}$ of $\mathrm{CH}_{3} \mathrm{COOH}$ as a co-catalyst.

4- The mixture is refluxed for 3 hours at $40^{\circ} \mathrm{C}$ temperature using a mechanical stirrer at moderate speed (700 rpm/minute), while stirring , $2 \mathrm{~g}$ of $\mathrm{Na}_{2} \mathrm{CO}_{3}$ is dissolved in $20 \mathrm{ml}$ of distilled water and added to the mixture . At the end of reaction, the mixture is left at room temperature for 30 minutes to attain phase separation . 
The $2^{\text {nd }}$ National Conference of Chemistry

5- The biphasic mixture is separated by extraction with acetonitrile and barium chloride three times. Obviously a precipitate formed in the aqueous layer when $\mathrm{BaCl}_{2}$ is added. This phenomenon suggests that the gas oil sulfur compounds are converted to $\mathrm{SO}_{4}{ }^{-2}$ during the oxidation $[9,10]$.

6 - The gas oil phase is withdrawn and the concentration of the remaining sulfur compounds is determined by X-ray Fluorescence (XRF) .

\section{Results and Discussion:}

Characterization of Catalysts:

Catalysts are characterized by X-ray diffraction (XRD) using diffractometer with $\mathrm{Cu} \mathrm{Ka}$ caradiation

$\left(1.5406{ }^{\circ} \mathrm{A} ; 40 \mathrm{kv} ; 30 \mathrm{~mA}\right)$ and step scan technique is in $2 \theta$ range of 20 to $60^{\circ}$.

The results of the $\mathrm{X}$ - ray diffraction of catalyst samples are shown in Table 3.

Table (3): Results of the X-ray Diffraction:

\begin{tabular}{|c|c|c|c|}
\hline Sample & $2 \theta$ (deg.) & $d\left(A^{\circ}\right)$ & $\mathbf{I} / \mathbf{I}_{0}$ \\
\hline \multirow{3}{*}{$\begin{array}{l}\mathrm{CoO} \\
\text { standard }\end{array}$} & 36.500 & 2.244 & $85 \%$ \\
\hline & 42.650 & 2.026 & $100 \%$ \\
\hline & 61.500 & 1.470 & $35 \%$ \\
\hline \multirow{3}{*}{$\begin{array}{l}\mathrm{NiO} \\
\text { standard }\end{array}$} & 37.248 & 2.411 & $60 \%$ \\
\hline & 43.286 & 2.088 & $100 \%$ \\
\hline & 62.852 & 1.477 & $30 \%$ \\
\hline \multirow{3}{*}{$\begin{array}{l}\text { Cat- A } \\
\text { Ni : Co } \\
70: 30\end{array}$} & 43.436 & 2.082 & $100 \%$ \\
\hline & 37.011 & 2.427 & $90 \%$ \\
\hline & 59.125 & 1.561 & $14 \%$ \\
\hline \multirow{3}{*}{$\begin{array}{l}\text { Cat-B } \\
\text { Ni : Co } \\
80: 20\end{array}$} & 43.201 & 2.093 & $100 \%$ \\
\hline & 37.136 & 2.419 & $66 \%$ \\
\hline & 36.087 & 2.487 & $6 \%$ \\
\hline
\end{tabular}

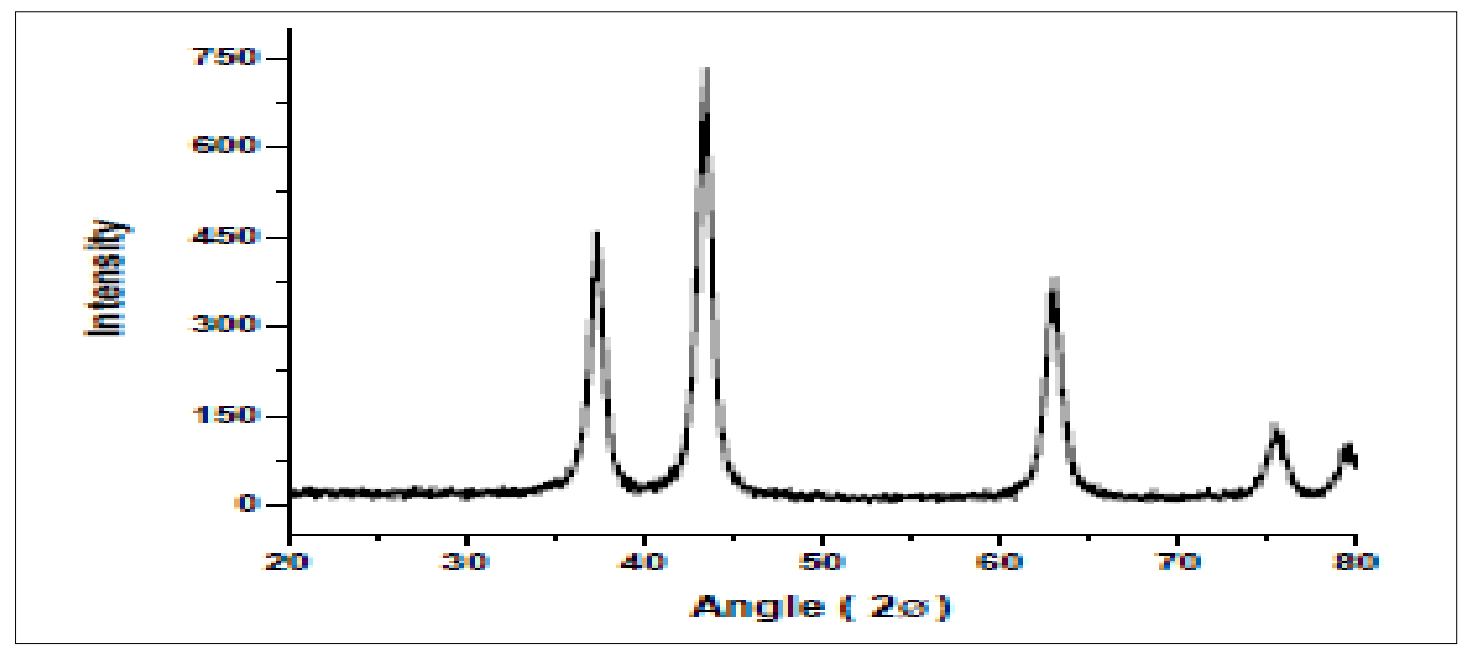

Fig (1): The X-ray Diffraction of Nickel Oxide ( NiO )[11] .

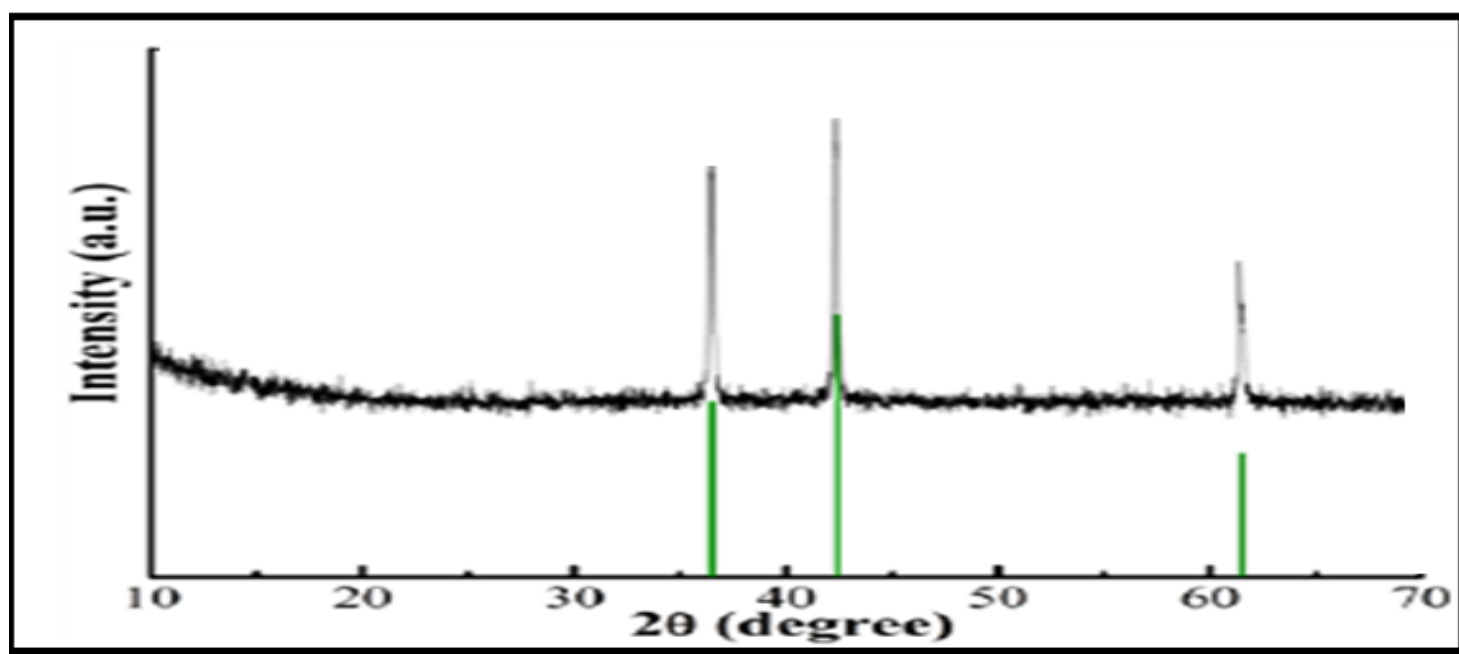

Fig (2): The X-ray Diffraction of Cobalt Oxide ( $\mathrm{CoO}$ )[12] • 


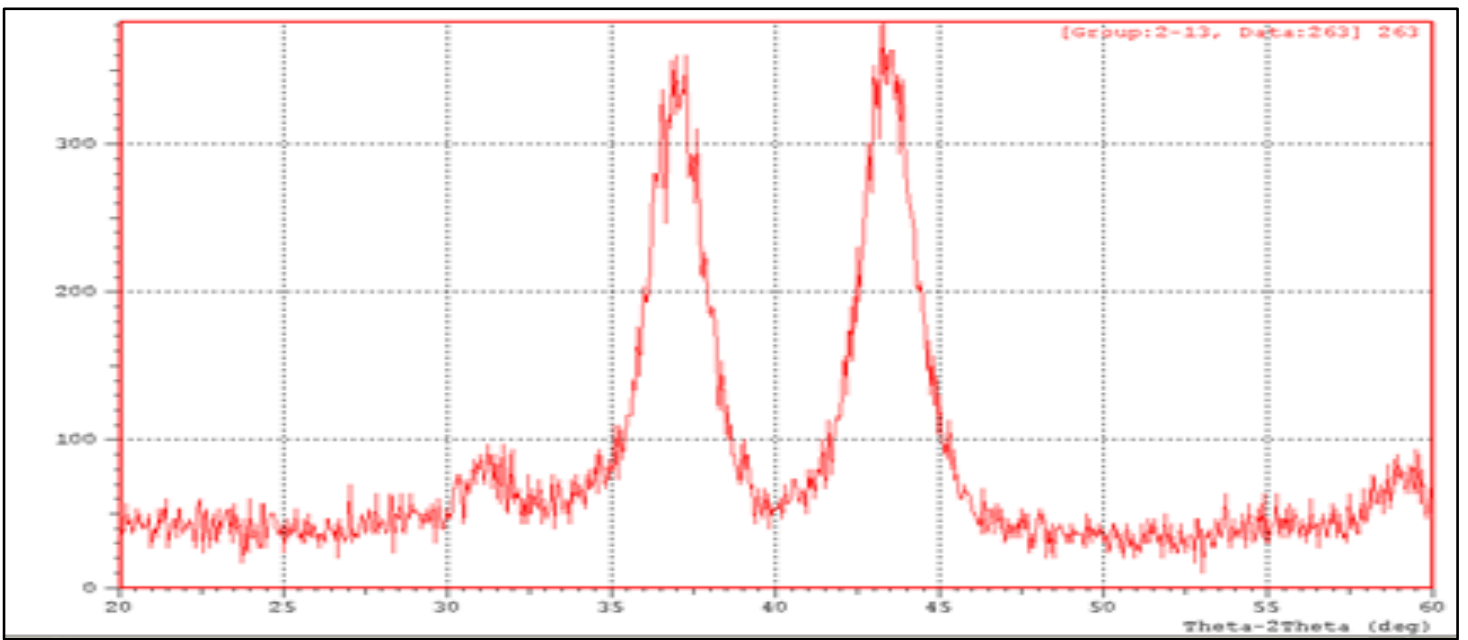

Fig (3 ): The X-ray Diffraction of Cat - A .

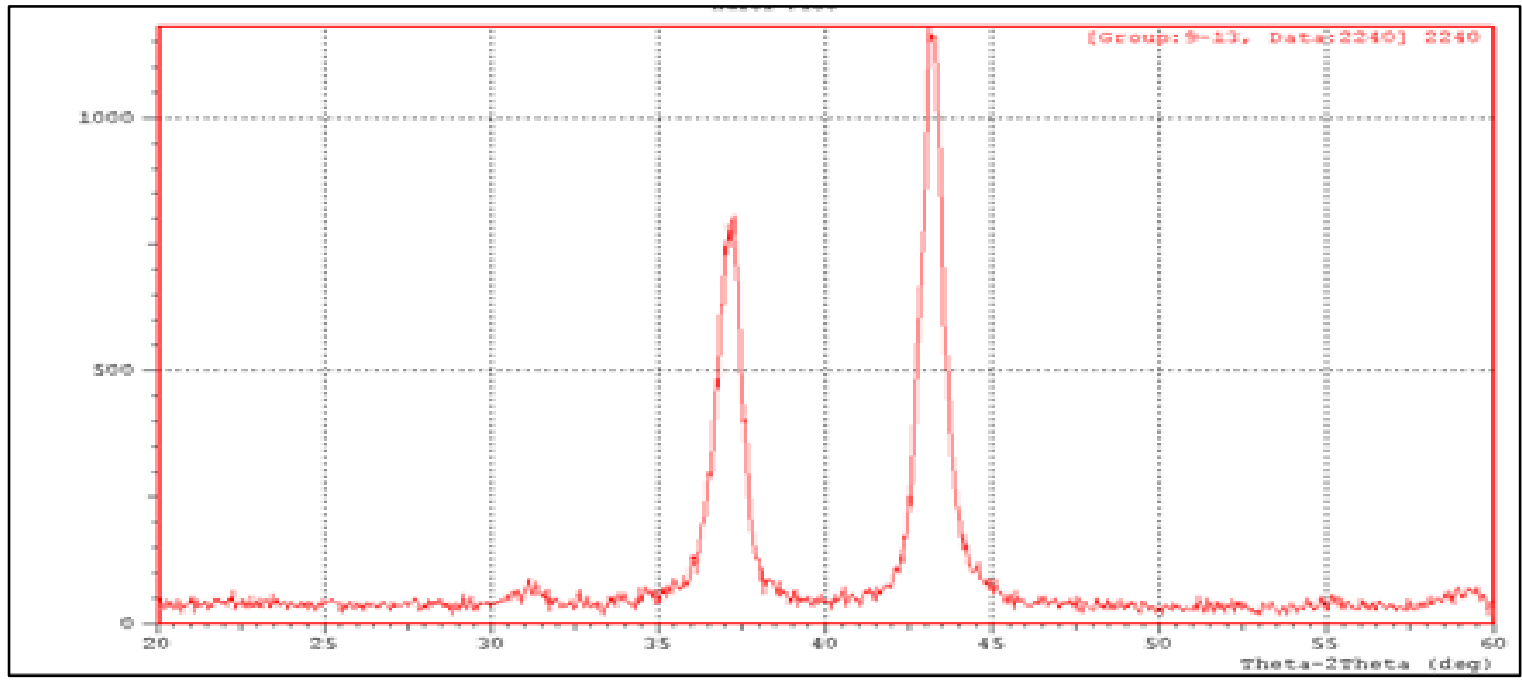

Fig (4): The X-ray Diffraction of Cat - B.

As shown in Table (3), the values of the diffraction are presented for $\mathrm{NiO}$ at $2 \theta \quad(37.248,43.286$ and 62.852 ) and for $\mathrm{CoO}$ at $2 \theta$ (36.5, 42.65 and 61.5 ), the catalysts nickelcobalt oxides display similar diffraction patterns compared to the standard diffraction $\mathrm{NiO}$ and $\mathrm{CoO}[11,12]$.

Furthermore from Table ( 3 ) and Figures ( 1 - 4 ) no apparent differences are observed in all catalysts nickel cobalt oxides, reveal between the XRD patterns of $\mathrm{Ni}$ - Co bimetallic catalyst and $\mathrm{NiO}$ or $\mathrm{CoO}$ monometallic catalyst because $\mathrm{Ni}^{2+}$ and $\mathrm{Co}^{2+}$ have similar lattice in the Ni-Co composite catalysts . The $\mathrm{Ni}^{2+}$ and $\mathrm{Co}^{2+}$ spinel-type solid solution and $\mathrm{NiCoO}_{2}$ spinel can be formed at high calcination temperatures, this is in good agreement with those reported in literature ${ }^{[13,14]}$. The values of diffraction peaks at $2 \theta(36.7,37.1$, 43.4 and 44.6) are observed in the catalysts with different $\mathrm{Ni}-\mathrm{Co}$ content. The reason for the difference in the values is related to the different calcining temperature where it is at 400 ${ }^{0} \mathrm{C}$ in this work compared with the $(500-900){ }^{\circ} \mathrm{C}$ in other studies $[15,16]$. The specific surface area and pore volume are measured according to the BET method. The results of the pore volume and surface area of catalyst samples are shown on Table 4. 
Table (4): Surface Area and Pore Volume Results :

\begin{tabular}{|l|l|l|l|}
\hline Catalyst & $\begin{array}{l}\text { Ratio } \\
\text { Ni : Co }\end{array}$ & $\begin{array}{l}\text { Surface } \\
\text { Area } \\
\mathbf{m}^{2} / \mathbf{g}\end{array}$ & $\begin{array}{l}\text { Pore } \\
\text { Volume } \\
\mathbf{c m}^{3} / \mathbf{g m} .\end{array}$ \\
\hline Cat- A & $70: 30$ & 72.971 & 0.200 \\
\hline Cat- B & $80: 20$ & 44.060 & 0.204 \\
\hline
\end{tabular}

A chemical analysis is conducted to catalysts $\mathrm{NiO}-\mathrm{CoO}$ to determine the percentages of the elements nickel and cobalt components in the $\mathrm{NiO}$ $\mathrm{CoO}$ catalysts by the atomic absorption technique. The results are listed on Table 5.

Table ( 5 ): Percentages of Nickel and Cobalt Elements and Oxides ( Found, Calculated ) Composing the Catalysts $\mathrm{NiO}-\mathrm{CoO}$.

\begin{tabular}{|c|c|c|c|c|c|c|c|c|c|}
\hline \multirow{2}{*}{$\begin{array}{c}\text { Catalyst } \\
\text { Code }\end{array}$} & \multicolumn{2}{|c|}{$\mathrm{Ni} \%$} & \multicolumn{2}{|c|}{$\mathrm{NiO} \%$} & \multicolumn{2}{|c|}{ Co\% } & \multicolumn{2}{|c|}{$\mathrm{CoO} \%$} & \multirow{2}{*}{$\begin{array}{c}\text { Total ratio of } \\
(\mathrm{F}) \\
\mathrm{NiO} \%+\mathrm{CoO} \%\end{array}$} \\
\hline & C & $\mathbf{F}$ & C & $\mathbf{F}$ & C & $\mathbf{F}$ & C & $\mathbf{F}$ & \\
\hline $\begin{array}{l}\text { Cat- A } \\
70: 30\end{array}$ & 54.92 & 54.12 & 69.89 & 68.87 & 23.63 & 22.96 & 30.05 & 29.19 & 98.06 \\
\hline $\begin{array}{l}\text { Cat- B } \\
80: 20\end{array}$ & 62.76 & 61.99 & 79.87 & 78.89 & 15.75 & 15.06 & 20.03 & 19.15 & 98.04 \\
\hline
\end{tabular}

$\mathbf{C}=$ Calculated, $\mathbf{F}=$ Found .

\section{Mechanism of Sulfur Removal:}

The removal of sulfur from gas oil is a very important global issue in order to decrease atmospheric pollution caused.

The (ODS) process has been studied in various systems, including oxidation (Hydrogen Peroxide) with organic acids. The catalytic oxidation of the sulfur compounds existing in the liquid hydrocarbons to form the corresponding sulfones and/ or sulfoxides improves significantly the extraction liquid-liquid separation process and the two liquid phases must be immiscible [17].

Also the mechanism can be represented as in the following scheme (1), which shows the effect of catalyst that takes $(\mathrm{O})$ from the oxidizing agent $\left(\mathrm{H}_{2} \mathrm{O}_{2}\right)$ giving this $(\mathrm{O})$ to oxidize the sulfur compounds into $\mathrm{SO}_{2}$.

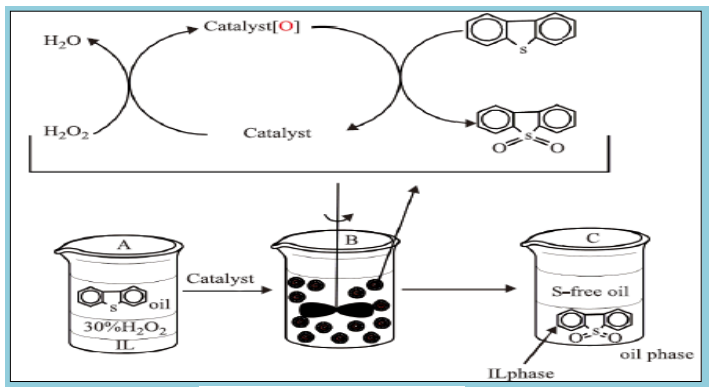

Liquid Phase

Scheme(1): Mechanism of The Oxidation Of Dibenzothiophene.

This (ODS) method, showing more energy efficient, cost effective and environment friendly, thus it could be a more promising process for deep desulfurization of the liquid hydrocarbon fuels.

\section{Determination of the Removal Efficiency of Sulfur Compounds}

The removal efficiency of sulfur compounds is calculated as the ratio of sulfur concentration that is oxidized in presence of catalyst and extracted (with acetonitrile and barium chloride) to the initial sulfur concentration in the gas oil used: 
The $2^{\text {nd }}$ National Conference of Chemistry

Desulfurization efficiency (\%)

$$
=\frac{S_{0}-S_{1}}{S_{0}} \times 100
$$

Where $\mathrm{S}_{0}$ is the initial S-content and $S_{1}$ is the final S-content after (ODS ). The results indicate that the catalyst is efficient to remove sulfur from gas oil with the catalyst., they are listed on Table (6).

Table (6): Results of The Removal Efficiency of Sulfur Compounds :

\begin{tabular}{|l|l|l|}
\hline Catalyst & Surface Area & Efficiency (\%) \\
\hline Cat- A & 72.971 & 68.97 \\
\hline Cat- B & 44.060 & 62.89 \\
\hline
\end{tabular}

The results indicate that the increase in the removal efficiency of sulfur compounds is due to the increase in the surface area, and more active sites.

The effect of temperature on the removal efficiency of sulfur compounds is determined at temperature (30,40 and 50) ${ }^{\circ} \mathrm{C}$.The ODS reaction efficiency results versus the three different temperatures at a constant time using catalyst (Cat- A) are shown on Table (7). A rise of temperature from 30 to $40{ }^{0} \mathrm{C}$ leads to a large increase in the removal efficiency of sulfur, however, the increase in temperature from 40 to $50{ }^{\circ} \mathrm{C}$ is less effective. This means that the increase in the temperature above $50{ }^{\circ} \mathrm{C}$ is not effective in such reaction as reported in literature $[10,18]$.

Table (7) Results of the Desulfurization Process in Different Temperature Using Catalyst (Cat- A ) at 2 Hours.

\begin{tabular}{|l|l|l|}
\hline $\begin{array}{l}\text { Experiment } \\
(\mathbf{n o})\end{array}$ & $\begin{array}{l}\text { Temperature } \\
\left(\begin{array}{c}\text { O })\end{array}\right.\end{array}$ & $\begin{array}{l}\text { Efficiency } \\
(\%)\end{array}$ \\
\hline $\mathbf{1}$ & 30 & 16.14 \\
\hline $\mathbf{2}$ & 40 & 51.78 \\
\hline $\mathbf{3}$ & 50 & 56.39 \\
\hline
\end{tabular}

Time is an important technical parameter for oxidation reactions, which reflects the oxidation reaction efficiency and determines the experimental time. As a whole, Table (8) shows that $\mathrm{S}$ content in the gas oil decreases with the increase of reaction time, while the efficiency of oxidative desulfurization (ODS) increases with the increase in reaction time.

Table (8): Results of the Desulfurization Process in Different Times at $40{ }^{\circ} \mathrm{C}$.

\begin{tabular}{|l|l|l|l|}
\hline $\begin{array}{l}\text { Experiment } \\
(\mathbf{n o})\end{array}$ & Catalyst & $\begin{array}{l}\text { Reaction } \\
\text { Time (h) }\end{array}$ & $\begin{array}{l}\text { Efficiency } \\
(\boldsymbol{\%})\end{array}$ \\
\hline $\mathbf{1}$ & Cat- A & 2 & 51.78 \\
\hline $\mathbf{2}$ & Cat- A & 3 & 68.97 \\
\hline
\end{tabular}

\section{Conclusions:}

The present study describes the preparation of $\mathrm{NiO}$ - CoO catalysts by precipitation using different $\mathrm{Ni}-\mathrm{Co}$ percentages. The catalysts are tested for the oxidative desulfurization of gas oil at selected parameters of oxidation temperature: $40{ }^{\circ} \mathrm{C}$, oxidation time: 3 hours. The oxidized sulfur compounds are extracted by acetonitrile. $\mathrm{NiO}$ - $\mathrm{CoO}$ catalysts prepared by the precipitation technique show high activity towards sulfur removal. The high surface area, sufficient pore volume are the reasons for this activity which reached $68.97 \%$.

\section{References:}

[1] Atkins, P. W.; Overton, T. L; Rourkem, J. P.; Weller, M. T.; and Armstrong, F. A. 2010. Inorganic chemistry, New York: W. H. Freeman and Company, $5^{\text {th }} \mathrm{Ed}, \mathrm{p}$. 690-720.

[2] IUPAC, Gold Book. 2012. Compendium of Chemical Terminology, Version 2.3.2, p. 220227.

[3] Hagen, J. 2006. Industrial Catalysis: A Practical Approach ,2nd Ed,Wiley- 
VCH Verlag $\mathrm{GmbH} \&$ Co. KGaA, Weinheim, p .1-58, p. 83-214.

[4] Farnetti, E.; Di Monte, R.; and KaŠper.; J.2009. Inorganic and BioInorganic Chemistry. EOLSS, Oxford :Eolss Publishers, (2) 1 -10.

[5] Turek, T.; Kneozinger, H.; Dutchmann, O.; and Kochloefl; K. 2009. Heterogeneous Catalysis and Solid Catalysts. Wiley-VCH Verlag $\mathrm{GmbH} \& \mathrm{Co}$ KGaA, Weinheim .p 1-110.

[6] Benson, R. E.; and Clifford; R. H. 2005. Controlling the Sulfur Content in Ultra Low Sulfur Diesel (ULSD) Fuels .

[7] Zhang, G.; Yu. F.; and Wang; R. 2009. Research advances in oxidative desulfurization technologies for the production of low sulfur fuel oils, Pet \& Coal 51(3):196-207.

[8] Perego, C.; and Villa, P. 1997. Catalyst preparation methods Cata $\mathrm{T}$, (34):281-305.

[9] Otsuki, S.; Nonaka, T.; Takashima, N.; Qian, W.; Ishihara, A.; Imai, T.; and Kabe; T. 2005. Oxidative

[10] Desulfurization of Light Gas Oil and Vacuum Gas Oil by Oxidation and Solvent Extraction, Ene \& Fuels, (11): 1232-1239.

[11] Jalil, T.; and Hasan, L;. F.2012. Oxidative desulfurization of gas oil using improving selectivity for active carbon of rice husk, DJPS,8( 3):6881 .

[12] Devadatha, D. and Raveendran, R. 2013. Structural and Dielectric Characterization of Nickel-Cobalt Oxide Nanocomposite, J. Material Sci Eng, S:11-003, 1-5 .

[13] Sun,Y.; Gao,S.; Lei,F.; Liu ,J.; Liang, L.; and Xie, Y.; .2014. Atomically thin Non-layered Cobalt Oxide Porous Sheets for Highly Efficient Oxygen-evolving Electrocatalysts, ESI for Chemical Science, p 1-6.
[14] Chang, S. k.; Zainal, Z.; Tan, K. B.; Yusof, N. A.; Yusoff, W. and Prabaharan S R. S. 2012. Surface Morphology and Crystallinity of Metal Oxides in Nickel-Cobalt Binary System. Sains Malaysiana 41(4):465-470.

[15] Zhang, J.; Wang, H.; and Dalai, A. K. 2008. Effects of metal content on activity and stability of Ni-Co bimetallic catalysts for $\mathrm{CO}_{2}$ reforming of $\mathrm{CH}_{4}$, Appl Catal A : General (339):121-129 .

[16] Li, H.; Berntsen, H.; Fernández, E.; Walmsley, J. C.; Blekkan E, A. and De, Chen. 2009. Co-Ni Catalysts Derived from Hydrotalcite-Like Materials for Hydrogen Production by Ethanol Steam Reforming, Top Catal (52):206-217.

[17] Kudashov, A. G.; Okotrub ,A. V.;Bulusheva ,L. G.;Asanov I, P.;Shubin,Yu. V.; Yudanov, N. F.; Yudanova ,L. I.; Danilovich ,V. S.; and Abrosimov,O. G. 2004. Influence of Ni-Co Catalyst Composition on Nitrogen Content in Carbon Nanotubes, J. Phys. Chem. B, (108): 9048-9053.

[18] Jianhua ,Ge.; Yuming ,Z. ;ong ,Y.; and Mengwei ,X; .2012. Catalytic oxidative desulfurization of gasoline using vanadium (V) -substituted Polyoxometalate $/ \mathrm{H}_{2} \mathrm{O}_{2}$ /ionic liquid emulsion system, China Pet \& Petrochemical Technology, 14(1): 25-31.

[19] Wang, X. j.; Fa-tang, Li.; Liu, J. x.; Kou, C. g.; Zhao, Y.; and Hao, Y. j. 2012. Preparation of $\mathrm{TiO} 2$ in Ionic,and Dishun Zhao Liquid via Microwave Radiation and in Situ Photocatalytic Oxidative Desulfurization of Diesel Oil. Ene \& Fuels , (26): 6777-6782. 


\section{تحضير وتمييز عـمل مساعد ثنائسي المـعـدن ( NiO -CoO ) لازالة الكبريـت من زيت الغاز}

\author{
اسماء هادي حسبن
}

\author{
جليل رهيف عكال \\ قسم الكيمياء - كلية العلوم للبنات - جامعة بغداد
}

الخلاصة:

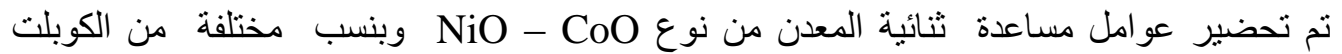

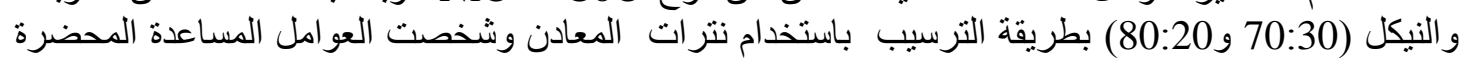

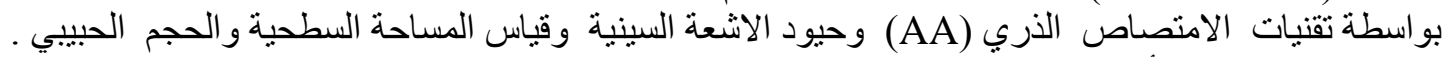

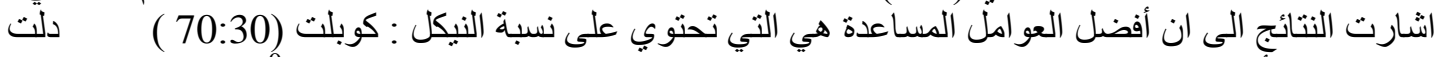

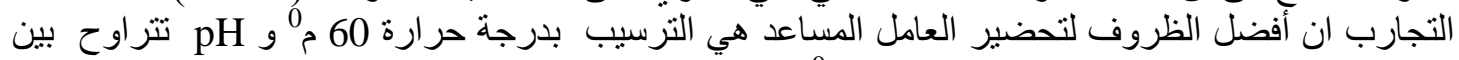

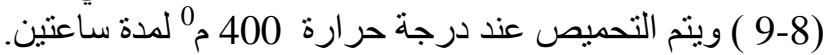

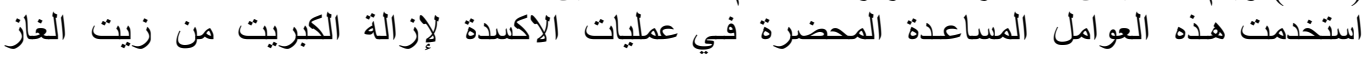

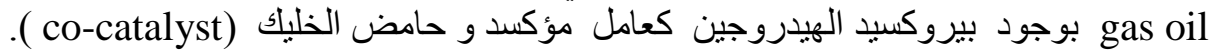

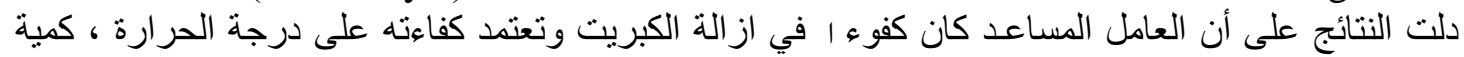

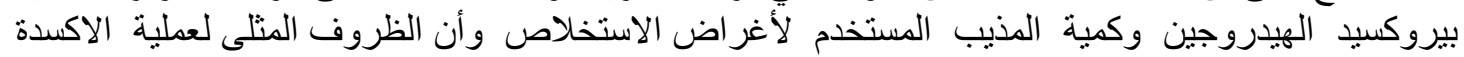

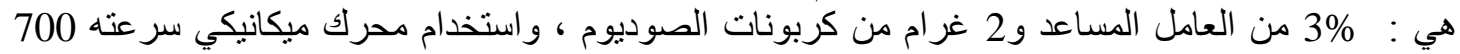

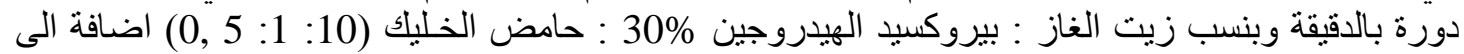
استخدام استيونتريل للاستخلاص بنسبة (1:1) ثلاث مر اتل وكات وكان زمن التصعيد ثلاث ساعات وبدرجة حرارة

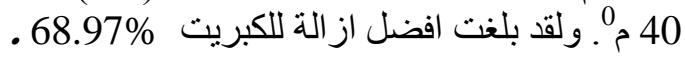
الكلمات المفتاحية : العو امل المساعدة ثنائية المعدن ، Ni-Co ، نزع الكبريت، زيت الغاز. 